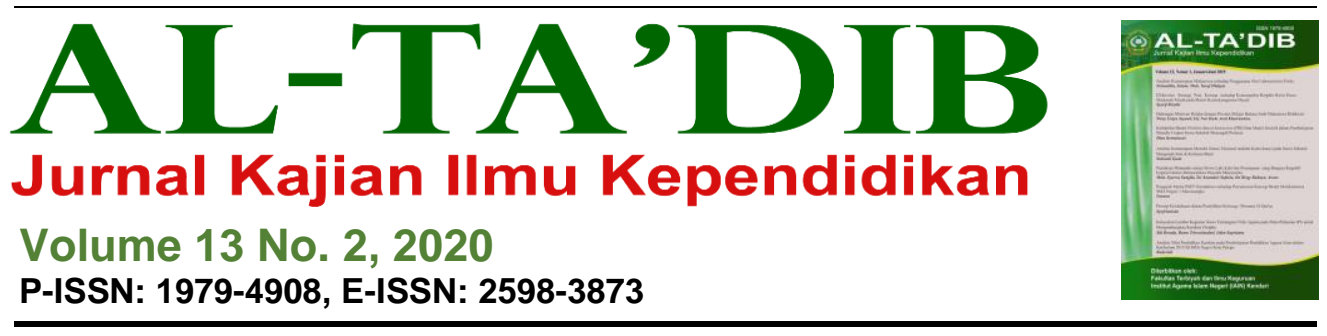

\title{
Peningkatan Hasil Belajar Matematika Siswa Menggunakan Model Pembelajaran Berbasis Masalah Berbantuan Multimedia Interaktif
}

\author{
Tandri Patih ${ }^{1}$, Halistin ${ }^{2}$, Muhammad Syarwa Sangila ${ }^{3}$, Imaludin Agus ${ }^{4}$, \\ Dedyerianto $^{5}$, Amanda La Hadi ${ }^{6}$, Nur Aini ${ }^{7}$, La Ode Sardin ${ }^{8}$, Samrin? \\ ${ }^{1}$ Institut Agama Islam Negeri Kendari, Indonesia, E-mail: tandripatih@iainkendari.ac.id \\ ${ }^{2}$ Institut Agama Islam Negeri Kendari, Indonesia, E-mail: halistin@iainkendari.ac.id \\ ${ }^{3}$ Institut Agama Islam Negeri Kendari, Indonesia, E-mail: syarwa1990@gmail.com \\ ${ }^{4}$ Institut Agama Islam Negeri Kendari, Indonesia, E-mail: maludinagus@iainkendari.ac.id \\ ${ }^{5}$ Institut Agama Islam Negeri Kendari, Indonesia, E-mail: dedyoke1987@ gmail.com \\ ${ }^{6}$ Institut Agama Islam Negeri Kendari, Indonesia, E-mail:amanda.lahadi@gmail.com \\ ${ }^{7}$ Institut Agama Islam Negeri Kendari, Indonesia, E-mail: nurainimtk@gmail.com \\ ${ }^{8}$ Institut Agama Islam Negeri Kendari, Indonesia, E-mail: sardinguali@gmail.com \\ ${ }^{9}$ Institut Agama Islam Negeri Kendari, Indonesia, E-mail: samrinsam75@yahoo.com
}

\section{ARTICLE INFO}

Keywords:

Interactive multimedia; junior high school; mathematics learning outcomes; problem based learning

How to Cite:

Patih, T., Halistin, Sangila, M. S., Agus, I.,

Dedyerianto, Hadi, A. L., Aini, N., Sardin, L. O., \& Samrin. (2020).

Peningkatan hasil belajar matematika siswa menggunakan model pembelajaran berbasis masalah berbantuan multimedia interaktif. $\mathrm{Al}$ Ta'dib: Jurnal Kajian Ilmu Kependidikan, 13(2), 65-77.

\begin{abstract}
This article reports the result of semi-experimental study which aims to determine and assess the improvement of students' mathematics learning outcomes after they are exposed to interactive multimedia-assisted problem-based learning model. The sample is 7 th grade students at one of junior high school in Kendari. They were selected using cluster random sampling technique. Based on the result of data analysis using descriptive and inferential statistics, the interactive multimedia assisted-problem based learning can improve the students' mathematics learning outcomes. The result of the study revealed the increase of the average after being taught with interactive multimedia assistedproblem based learning models with 21.2 units and the significance value of 0.00. Interactive multimedia-assistedproblem based learning can be an alternative for mathematical activeness and abilities, which have an impact on improving student mathematics learning outcomes.
\end{abstract}


INFORMASI ARTIKEL

Kata Kunci:

Hasil belajar matematika; multimedia interaktif; pembelajaran berbasis masalah; sekolah menengah pertama

Cara Mensitasi:

Patih, T., Halistin, Sangila, M. S., Agus, I., Dedyerianto, Hadi, A. L., Aini, N., Sardin, L. O., \& Samrin. (2020).

Peningkatan hasil belajar matematika siswa menggunakan model pembelajaran berbasis masalah berbantuan multimedia interaktif. $A l$ Ta'dib: Jurnal Kajian Ilmu Kependidikan, 13(2), 65-77.

\begin{abstract}
ABSTRAK
Artikel ini melaporkan hasil penelitian semi eksperimental yang bertujuan untuk mengetahui dan mengkaji peningkatan hasil belajar matematika siswa setelah diajar dengan model pembelajaran berbasis masalah berbantuan multimedia interaktif. Sampel penelitian adalah siswa kelas VII di salah satu sekolah menengah pertama negeri di kota Kendari yang dipilih menggunakan teknik cluster random sampling. Hasil analisis data menunjukkan bahwa baik secara deskriptif maupun secara inferensial, pembelajaran berbasis masalah berbantuan multimedia interaktif dapat meningkatkan hasil belajar matematika siswa. Peningkatan rata-rata hasil belajar matematika siswa sesudah diajar dengan model pembelajaran berbasis masalah berbantuan multimedia interaktif sebesar 21,2 satuan dengan nilai signifikansi sebesar 0,00. Dengan demikian, pembelajaran berbasis masalah berbantuan multimedia interaktif dapat menjadi alternatif bagi guru matematika untuk meningkatkan keaktifan dan kemampuan matematik siswa, yang berdampak pada peningkatan hasil belajar matematika mereka.
\end{abstract}

\section{Pendahuluan}

Matematika merupakan bidang ilmu yang berperan penting dalam perkembangan ilmu pengetahuan dan teknologi. Matematika dapat membentuk dan meningkatkan kemampuan berpikir logis, analitis, sistematis, kritis, dan kreatif siswa. Selain itu, matematika juga dapat membentuk dan meningkatkan kemampuan bekerjasama siswa yang menjadi salah satu modal mental dalam menghadapi persaingan global (Halistin, 2018). Matematika memiliki sifat hirarki. Untuk memahami matematika lanjutan, siswa harus mampu memahami dan memiliki pengetahuan dasar matematika. Kehirarkian dan pengurutan materi pembelajaran berpengaruh pada pengetahuan yang dikonstruksi siswa (Fyfe, DeCaro \& Rittle-Johnson, 2014). Dengan kata lain, siswa harus mampu memahami pokok bahasan yang diajarkan pada setiap jenjang pendidikan untuk dapat memahami pokok bahasan pada jenjang yang lebih tinggi. Pokok bahasan bilangan pada tingkatan sekolah dasar dan menengah (bilangan bulat dan pecahan) merupakan prasyarat penting untuk matematika yang lebih tinggi (Hurst \& Cordes, 2018). 
Penelitian yang mengkaji tentang kemampuan bilangan bulat dan pecahan siswa banyak lakukan di berbagai belahan dunia (Boyce \& Norton, 2016; DeWolf, Bassok \& Hollyoak, 2015a, 2015b; Fyfe, dkk., 2014; Hadi \& Dedyerianto, 2020; Halistin, 2018; Halistin, Kadir \& Masi, 2015; Hui, 2014; Hurst \& Cordes, 2018; Maonde, Bey \& Adawia, 2017; Siegler, Clarissa \& Schneider, 2011). Boyce dan Norton (2016) menegaskan bahwa bilangan bulat dan pecahan merupakan dua hal yang erat kaitannya. Pecahan merupakan pokok bahasan yang paling penting bagi siswa tingkat sekolah dasar dan menengah dalam mengembangkan pemahamannya pada bilangan bulat (Boyce \& Norton, 2016; Hurst \& Cordes, 2018). Selain itu, kemampuan bilangan juga berperan penting dalam mempengaruhi kemampuan aljabar, geometri dan pengukuran, serta statistika dan pengolahan data (Patih, 2016). Kemampuan pecahan siswa menggunakan garis bilangan dapat memprediksi kemampuan aljabarnya, utamanya pada ukuran pengetahuan pecahan rasional dan kemampuan untuk menempatkan desimal pada garis bilangan (DeWolf, dkk., 2015b). Akan tetapi, dibalik pentingnya bilangan bulat dan pecahan ini, masih terdapat sejumlah masalah yang ditemui. Penelitian menunjukkan bahwa beberapa siswa belum bisa menafsirkan representasi simbolis dari bilangan bulat negatif (Schindler \& Hußmann, 2013), pemahaman siswa tentang pecahan masih membingungkan dan tidak lengkap, dan siswa juga menggunakan strategi yang salah dalam mengoperasikan pecahan (Hui, 2014).

Di Indonesia, kemampuan siswa yang rendah masih menjadi masalah yang masih sulit dipecahkan (Pinahayu, 2017). Masih banyak siswa yang mengalami kesulitan untuk menyelesaikan masalah yang berkaitan dengan kehidupan sehari-hari ataupun masalah-masalah matematika sederhana. Hasil penelitian Sitriani, Kadir, Arapu, dan Ndia (2019) mengungkapkan bahwa rata-rata kemampuan numerik siswa, baik laki-laki maupun perempuan, masih berada pada level yang rendah. Kemampuan numerik ini sendiri merupakan kemampuan matematik yang berhubungan dengan pengetahuan dan pemahaman siswa terhadap konsep bilangan dan operasinya. Hal tersebut pada umumnya dikarenakan siswa masih merasa bingung dengan hal-hal yang dibutuhkan dan metode penyelesaian masalah yang harus digunakan dalam menyelesaikan masalah tersebut. Disamping itu, masih rendahnya kemampuan dasar operasi bilangan bulat dan pecahan siswa juga menjadi kendala utama dalam menyelesaikan masalah matematika siswa (Hadi \& Dedyerianto, 2020; Halistin, dkk., 2015; Maonde, dkk., 2017). Hal ini tentu tidak terlepas dari pembelajaran di sekolah. Siegler, dkk., (2011) mengungkapkan bahwa mengembangkan strategi yang efektif memainkan peran kunci dalam meningkatkan pengetahuan siswa.

Dalam pembelajaran, siswa masih kesulitan untuk menghubungkan pengetahuan, informasi yang dimiliki dan masalah yang dihadapi. 
Pengetahuan yang dipelajari siswa seharusnya bukan informasi yang tidak mengalami pembaharuan, tetapi pengetahuan yang berguna (useful) dan hidup (alive) ketika di terapkan sebagai solusi untuk beberapa masalah (Jacobsen, dkk., 2009). Oleh karena itu, pendidikan yang mereka peroleh seharusnya mampu membentuk siswa menjadi pembelajar yang cerdas dan mampu menyelesaikan persoalan yang mereka hadapi di kemudian hari. Pembelajaran yang berarti bagi siswa dapat diangkat dari pembelajaran berdasarkan masalah. Pembelajaran ini dimulai dari masalah sehari-hari dari kehidupan nyata dan bermakna. Menurut Pehkonen dalam Siswono (2018), agar bermanfaat untuk pembelajaran maka siswa menghubungkan informasiinformasi yang diketahui dan informasi tugas yang harus dikerjakan sehingga tugas itu merupakan hal baru bagi mereka.

Model pembelajaran berbasis masalah (problem based learning) merupakan suatu model dimana siswa dihadapkan pada masalah autentik atau masalah nyata yang memerlukan pemecahan masalah (Putra, Sudia \& Arapu, 2020). Pembelajaran berbasis masalah terbukti efektif dalam mengembangkan kemampuan penalaran dan penerapan sains (Merritt, Lee, Rillero, \& Kinach 2017). Selain itu, model ini juga efektif dalam meningkatkan kemampuan siswa untuk bekerjasama dalam menyelesaikan masalah matematika. Dalam pembelajaran berbasis masalah, siswa belajar bersama dalam kelompok kecil. Situasi ini memungkinkan siswa untuk mengaktifkan pengetahuan awalnya melalui diskusi. Disamping itu, guru juga terlibat dalam memfasilitasi pembelajaran. Oleh karena itu, hasil belajar siswa dapat ditingkatkan (Tarmizi \& Bayat, 2012).

Tujuan utama pembelajaran berbasis masalah (PBL) adalah untuk meningkatkan penerapan pengetahuan, pemecahan masalah, dan keterampilan pembelajaran mandiri siswa yang mengharuskan menuntut keaktifan mereka mengartikulasikan, memahami, dan memecahkan masalah. Strategi-strategi PBL menurut Jacobsen, Eggen, dan Kauchak (2009) memiliki karakteristik sebagai berikut: 1) pelajaran dimulai dengan mengangkat suatu permasalahan atau satu pertanyaan yang nantinya menjadi focal point untuk keperluan usaha-usaha investigasi siswa; 2) siswa memiliki tanggung jawab utama dalam menyelidiki masalah-masalah dan mengejar pertanyaan-pertanyaan; 3) guru dalam pembelajaran berbasis masalah berperan sebagai fasilitator. Banyak penelitian menunjukkan bagaimana PBL dapat meningkatkan hasil belajar. Akan tetapi, pendekatan ini juga memiliki sejumlah kekurangan. Karena PBL ini membutuhkan waktu yang relatif lama, guru kesulitan dalam memposisikan dirinya sebagai fasilitator, pembimbing dan pendukung inisiatif siswa (Tyas, 2017). Hal ini erat kaitannya dengan alokasi waktu 2 atau 3 jam pelajaran ( 2 atau $3 \times 40$ menit) dalam tiap pertemuan di kelas yang dinilai tidak cukup dan menyulitkan guru untuk menyelesaikan prosedur model pembelajaran ini. Oleh karena itu, guru 
butuh alternatif lain yang dapat membantu menyempurnakan penggunaan model pembelajaran ini.

Penggunaan media dinilai efektif untuk membantu keterbatasan waktu dan kesulitan guru dalam menerapkan model PBL. Perpaduan penggunaan pembelajaran berbasis masalah dengan multimedia terbukti memberi dampak positif bagi kemampuan matematis siswa (Kalimatusadiah, dkk., 2019; Khasanah \& Hartono, 2017; Khoiri, dkk., 2013). Multimedia interaktif merupakan media pembelajaran yang mengkombinasikan beberapa media (audio, video, teks atau grafik) yang bersifat interaktif untuk mengendalikan suatu perintah atau perilaku alami dari suatu presentasi sehingga terjadi hubungan dua arah antara media pembelajaran dengan penggunanya (Kalimatusadiah, dkk., 2019). Penelitian sebelumnya yang dilakukan oleh Kalimatusadiah, Runiah dan Lestari (2019), Khasanah dan Hartono (2017), dan Khoiri, Rochmad dan Cahyono (2013) telah mengembangkan dan menggunakan multimedia interaktif pada beberapa pokok bahasan matematika. Akan tetapi, media yang dikembangkan dan digunakan dalam penelitian-penelitian relevan tersebut belum membahas tentang pokok bahasan bilangan bulat dan pecahan. Dengan melihat urgensi dan peran dari penguasaan materi bilangan bulat dan pecahan yang telah dijelaskan sebelumnya, penting untuk mengetahui dan membahas sejauh mana pemberlakuan PBL berbantuan multimedia interaktif dapat meningkatkan hasil belajar matematika siswa SMP Negeri di kota Kendari pada pokok bahasan bilangan bulat dan pecahan.

\section{Metode Penelitian}

Penelitian ini merupakan penelitian kuantitatif-eksperimen dengan desain eksperimen one-group pretest-posttest. Populasi dalam penelitian ini merupakan seluruh siswa kelas VII di salah satu SMP negeri di Kota Kendari yang tersebar dalam 7 kelas paralel. Pemilihan sampel dilakukan menggunakan teknik cluster random sampling dengan memilih 2 kelas sampel dari populasi. Setelah dua kelas terpilih, selanjutnya peneliti melakukan koordinasi dengan guru mata pelajaran mengenai sampel penelitian, waktu pelaksanaan, dan peran dalam penelitian ini. Setelah negosiasi akses penelitian dilakukan, peneliti diperkenalkan sebagai pengajar pada kelas penelitian selama penelitian berlangsung. Pada kedua kelas yang terpilih menjadi sampel tersebut diterapkan perlakuan yang sama, yakni pembelajaran matematika berbasis masalah berbantuan multimedia interaktif pada pokok bahasan operasi bilangan bulat dan pecahan. Multimedia interaktif dalam penelitian ini berbentuk powerpoint slide show (.pptxs) yang dirancang sedemikian rupa sehingga memiliki efek suara, gambar, dan tombol-tombol navigasi interaktif yang menarik. Multimedia interaktif ini 
telah melalui proses validasi materi dan media sebelum digunakan. Proses PBL dalam penelitian ini mengikuti beberapa langkah pembelajaran. Sintaks PBL dapat dilihat pada Tabel 1 (Darlia, Nasriani \& Fajri, 2018).

Tabel 1. Sintaks Pembelajaran Berbasis Masalah

\begin{tabular}{|c|c|c|}
\hline Fase & Indikator & Aktifitas/Kegiatan Guru \\
\hline 1 & $\begin{array}{l}\text { Orientasi siswa pada } \\
\text { masalah }\end{array}$ & $\begin{array}{l}\text { Guru menjelaskan tujuan pembelajaran, } \\
\text { menjelaskan logistik yang diperlukan, mengajukan } \\
\text { masalah, memotivasi siswa yang terlibat dalam } \\
\text { aktifitas pemecahan masalah yang dipilihnya }\end{array}$ \\
\hline 2 & $\begin{array}{l}\text { Mengorganisasikan siswa } \\
\text { untuk belajar }\end{array}$ & $\begin{array}{l}\text { Guru membantu sisiwa mendefinisikan dan } \\
\text { mengorganisasikan tugas belajar yang } \\
\text { berhubungan dengan masalah tersebut }\end{array}$ \\
\hline 3 & $\begin{array}{l}\text { Membimbing penyelidikan } \\
\text { individual maupun } \\
\text { kelompok }\end{array}$ & $\begin{array}{l}\text { Guru mendorong siswa untuk mengumpulkan } \\
\text { informasi yang sesuai, melakukan eksperimen, } \\
\text { untuk mendapatkan penjelasan pemecahan } \\
\text { masalah }\end{array}$ \\
\hline 4 & $\begin{array}{l}\text { Mengembangkan dan } \\
\text { menyajikan hasil karya }\end{array}$ & $\begin{array}{l}\text { Guru membantu siswa dalam merencanakan dan } \\
\text { menyiapkan karya yang sesuai seperti laporan, } \\
\text { video, model dan membantu mereka untuk berbagi } \\
\text { tugas dengan kelompoknya }\end{array}$ \\
\hline 5 & $\begin{array}{l}\text { Menganalisa dan } \\
\text { mengevaluasi proses } \\
\text { pemecahan masalah }\end{array}$ & $\begin{array}{l}\text { Guru membantu siswa melakukan refleksi atau } \\
\text { evaluasi terhadap penyelidikan mereka dalam } \\
\text { proses-proses yang mereka gunakan }\end{array}$ \\
\hline
\end{tabular}

Proses pembelajaran dalam penelitian ini dilakukan selama enam kali pertemuan. Sebelum perlakuan dilaksanakan, siswa diberikan pretest untuk mengukur hasil belajar matematika mereka pada materi bilangan bulat dan pecahan. Pada akhir perlakuan, siswa diberikan posttest untuk mengukur hasil belajar matematika siswa dengan soal yang sama. Soal-soal yang diteskan meliputi penjumlahan dan pengurangan bilangan bulat dan pecahan, perkalian dan pembagian bilangan bulat dan pecahan, serta pemecahan masalah matematika yang berkaitan dengan operasi bilangan bulat dan pecahan. Dalam penelitian ini, penulis pertama, yang juga dosen matakuliah media pembelajaran di salah satu perguruan tinggi di Sulawesi Tenggara, bertindak sebagai pengajar sedangkan penulis lainnya dan guru mata pelajaran bertindak sebagai observer.

\section{Hasil dan Pembahasan}

\subsection{Analisis Hasil Belajar Matematika Siswa}

Hasil penelitian ini diawali dengan analisis terhadap hasil belajar matematika siswa secara deskriptif dan inferensial. Hasil analisis deskriptis dapat dilihat 
pada Gambar 1. Berdasarkan hasil analisis yang disajikan pada Gambar 1 dapat diketahui bahwa secara deskriptif, rata-rata hasil belajar matematika siswa pada materi operasi bilangan bulat dan pecahan setelah diajar menggunakan model pembelajaran berbasis masalah berbantuan multimedia interaktif (posttest) mengalami peningkatan.

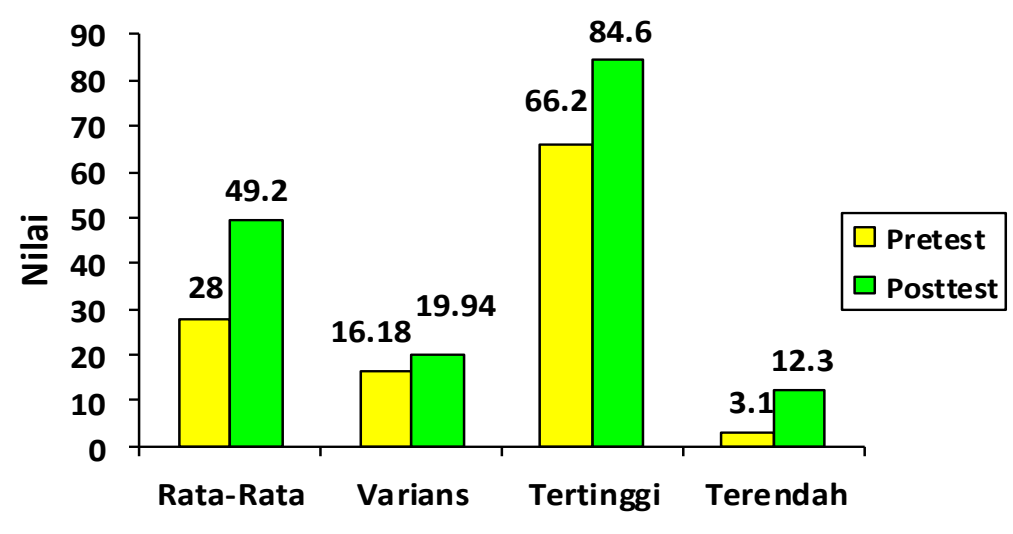

Gambar 1. Statistik Hasil Belajar Matematika Siswa

Keragaman (varians) nilai siswa setelah pembelajaran dilakukan pun lebih tinggi dibanding sebelum menggunakan model pembelajaran berbasis masalah berbantuan multimedia (pretest). Lebih jelasnya lagi dapat dilihat pada Gambar 2. Berdasarkan nilai tertinggi dan terendah juga terlihat bahwa terdapat peningkatan nilai yang cukup baik, dimana nilai tertinggi siswa mencapai 84,6 dibanding sebelum diajar menggunakan model pembelajaran berbasis masalah berbantuan multimedia interaktif yakni sebesar 66,2. Atau dengan kata lain nilai tertinggi siswa meningkat sebesar 18,4 satuan.

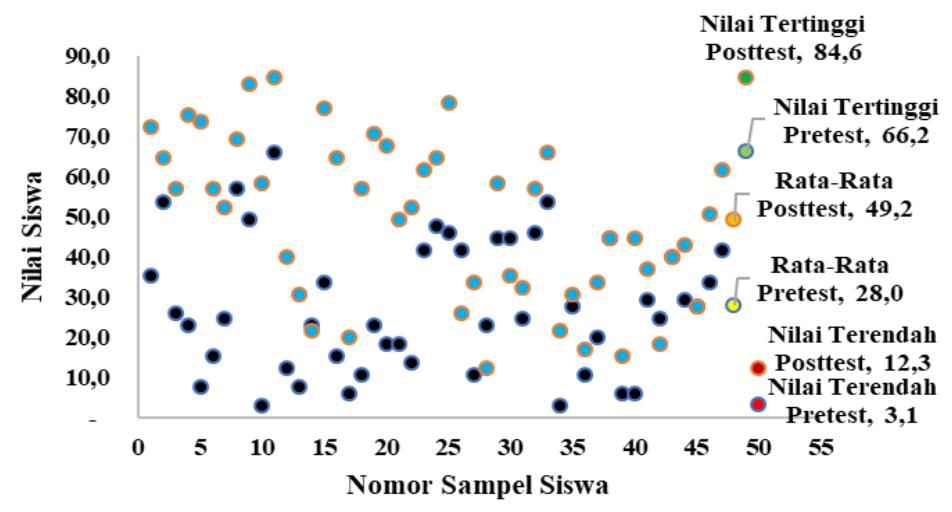

Gambar 2. Sebaran Data Hasil Belajar Matematika Siswa 
Untuk mengetahui apakah hasil belajar matematika siswa mengalami peningkatan yang signifikan setelah diajar menggunakan model pembelajaran berbasis masalah berbantuan multimedia interaktif, dilakukan pengujian hipotesis statistik menggunakan uji t sampel berpasangan (paired sample t-test) dengan terlebih dahulu melalukan pengujian normalitas data. Data dikatakan memenuhi asumsi normalitas jika nilai signifikansi pengujian lebih besar dari nilai $\alpha=0,05$ yang dapat dilihat pada Tabel 2. Berdasarkan hasil analisis data yang disajikan pada Tabel 2, diketahui bahwa data pretest dan posttest hasil belajar siswa telah memenuhi asumsi distribusi normal. Oleh karena itu, analisis inferensial selanjutnya dapat dilakukan menggunakan statistika parametrik uji $\mathrm{t}$ sampel berpasangan.

Tabel 2. Uji Normalitas Data Hasil Belajar Matematika Siswa

\begin{tabular}{|c|c|c|c|}
\hline \multirow[b]{2}{*}{ Variabel } & \multicolumn{2}{|c|}{ Signifikansi (P-value) } & \multirow[b]{2}{*}{ Keputusan } \\
\hline & $\begin{array}{l}\text { Kolmogorov- } \\
\text { Smirnov Test }\end{array}$ & $\begin{array}{c}\text { Shapiro-Wilk } \\
\text { Test }\end{array}$ & \\
\hline $\begin{array}{l}\text { Pretest Hasil Belajar } \\
\text { Matematika Siswa }\end{array}$ & 0,200 & 0,099 & $\begin{array}{l}\text { Berdistribusi } \\
\text { Normal }\end{array}$ \\
\hline $\begin{array}{l}\text { Posttest Hasil Belajar } \\
\text { Matematika Siswa }\end{array}$ & 0,106 & 0,138 & $\begin{array}{c}\text { Berdistribusi } \\
\text { Normal }\end{array}$ \\
\hline
\end{tabular}

Uji t sampel berpasangan dilakukan untuk melihat signifikansi peningkatan hasil belajar matematika siswa yang diajar menggunakan model pembelajaran berbasis masalah berbantuan multimedia interaktif. Hipotesis statistik yang diuji dalam penelitian ini adalah:

$\mathrm{H}_{0}$ : Tidak terdapat peningkatan hasil belajar matematika siswa yang signifikan setelah diajar menggunakan model pembelajaran berbasis masalah berbantuan multimedia interaktif

$\mathrm{H}_{1}$ : Terdapat peningkatan hasil belajar matematika siswa yang signifikan setelah diajar menggunakan model pembelajaran berbasis masalah berbantuan multimedia interaktif

Tabel 3. Hasil Uji t Sampel Berpasangan Peningkatan Hasil Belajar Matematika Siswa

\begin{tabular}{lcccc}
\hline \multirow{2}{*}{ Variabel } & \multicolumn{3}{c}{ Statistik } & Keputusan \\
\cline { 2 - 4 } & $\begin{array}{c}\text { Rata-rata } \\
\text { Perbedaan }\end{array}$ & $\begin{array}{c}\text { Nilai t } \\
\text { Hitung }\end{array}$ & $\begin{array}{c}P- \\
\text { Value }\end{array}$ & \\
\hline $\begin{array}{l}\text { Pretest Hasil Belajar } \\
\text { Matematika Siswa - }\end{array}$ & 21,20 & 7,58 & 0,00 & Tolak $\mathrm{H}_{0}$ \\
$\begin{array}{l}\text { Posttest Hasil Belajar } \\
\text { Matematika Siswa }\end{array}$ & & & & \\
\hline
\end{tabular}


Pengujian hipotesis statistik dilakukan pada $\alpha=0,05$. Jika nilai probabilitas uji t lebih besar dari nilai $\alpha$ ( $p$-value < 0,05$)$, maka keputusan yang diambil adalah menolak $\mathrm{H}_{0}$. Hasil pengujian tersebut dapat dilihat pada Tabel 3. Berdasarkan hasil pengujian hipotesis yang disajikan pada Tabel 3, dapat diketahui bahwa terdapat peningkatan hasil belajar matematika siswa yang signifikan setelah diajar menggunakan model pembelajaran berbasis masalah berbantuan multimedia interaktif. Hal ini terlihat dari nilai probabilitas uji t yang lebih besar dari nilai $\alpha(p$-value $=0,00>0,05)$ atau dengan kata lain $\mathrm{H}_{0}$ ditolak.

\subsection{Pembelajaran Berbasis Masalah dalam Pembelajaran Matematika}

Pembelajaran berbasis masalah (PBL) merupakan salah satu model pembelajaran yang memfokuskan siswa pada pemecahan masalah yang nyata, sehingga siswa dituntut untuk lebih aktif terlibat dalam proses pembelajaran. Arends (2012) menjelaskan bahwa model PBL merupakan model mengajar yang berfokus pada pemecahan masalah yang nyata karena peserta didik terlibat dalam proses kolaboratif melalui kerja kelompok, umpan balik dan diskusi yang dapat berfungsi untuk investigasi dan penyelidikan laporan akhir. Proses tersebut membutuhkan media sebagai alat dalam menyampaikan atau mengantarkan pesan-pesan pengajaran dari guru ke peserta didik (Khasanah \& Hartono, 2017). Oleh karena itu, pembelajaran dengan memanfaatkan multimedia interaktif perlu dilakukan, khususnya pada pembelajaran berbasis masalah karena pemanfaatan multimedia interaktif pada PBL dapat meningkatkan aktivitas pembelajaran siswa. Multimedia interaktif juga dapat membangkitkan minat dan meningkatkan motivasi siswa untuk belajar matematika (Sukmana, Candiasa \& Kirna, 2013).

Hasil analisis deskriptif dalam penelitian ini memperlihatkan rata-rata hasil belajar matematika siswa mengalami peningkatan sebesar 75,7\% (dihitung dari $\frac{49,2-28}{28} \times 100 \%$ ), yang menjelaskan bahwa secara deskriptif pembelajaran berbasis masalah berbantuan multimedia interaktif dapat meningkatkan hasil belajar matematika siswa di kelas yang diberi perlakuan. Nilai varians hasil belajar siswa juga mengalami peningkatan sebesar 3,76 satuan. Hal ini menjelaskan bahwa kemampuan matematika siswa berdasarkan hasil belajarnya setelah diajar menggunakan PBL berbantuan multimedia interaktif lebih beragam dibandingkan sebelumnya. Keragaman siswa setelah diajar menggunakan PBL berbantuan multimedia interaktif juga terlihat baik dibandingkan sebelumnya, seperti yang ditunjukkan pada Gambar 2, sebaran nilai-nilai siswa banyak yang berada disekitar nilai 
tertinggi yaitu sebesar 84,6. Berdasarkan Gambar 2 juga, terlihat bahwa hampir keseluruhan siswa mengalami peningkatan hasil belajar. Peningkatan statistik hasil belajar matematika siswa juga terjadi pada nilai terendah dan nilai tertinggi yang diperoleh siswa. Hasil ini serupa dengan hasil penelitian yang dilakukan oleh Pertiwi dan Dibia (2018) yang mengungkapkan bahwa penerapan model PBL berbantuan media interaktif dapat meningkatkan persentase rata-rata hasil belajar matematika siswa sebesar 7,35\%. Hendra (2016) juga menegaskan dalam penelitiannya bahwa penerapan media pembelajaran berbasis komputer model tutorial interaktif dalam proses pembelajaran dapat meningkatkan hasil belajar matematika siswa.

Hasil analisis deskriptif tersebut diperkuat oleh hasil analisis inferensial melalui pengujian hipotesis statistik menggunakan uji t sampel berpasangan (paired sample t-test). Hasil pengujian mengungkapkan bahwa rata-rata hasil belajar matematika siswa meningkat secara signifikan dengan perbedaan rata-rata sebesar 21,2 satuan dan nilai probabilitas ( $p$-value) sebesar 0,00 (lebih kecil dari $\alpha=0,05$ ). Hal ini mempertegas bahwa PBL berbantuan multimedia interaktif dapat meningkatkan hasil belajar matematika siswa kelas VII secara signifikan. Hasil penelitian ini sejalan dengan yang diungkapkan oleh Gufron, Darwan dan Winarso (2018) dalam penelitian mereka bahwa pembelajaran matematika yang menggunakan multimedia interaktif berpengaruh signifikan terhadap hasil belajar siswa, baik pada ranah afektif, psikomotorik, maupun kognitif. Lebih lanjut, penelitian Sartika (2017) menegaskan bahwa model PBL berbantuan media pembelajaran interaktif berpengaruh terhadap kemampuan pemahaman konsep matematika, kemampuan komunikasi matematika, dan kemampuan penalaran matematika siswa. Kemampuan-kemampuan matematika ini merupakan hard skill matematika yang harus dimiliki oleh siswa untuk menunjang hasil belajar matematika yang lebih baik. Hasil penelitian ini juga mengonfirmasi hasil penelitian Pertiwi dan Dibia (2018) yang juga mengungkapkan bahwa penerapan model PBL berbantuan media interaktif dapat meningkatkan hasil belajar matematika siswa.

\section{Kesimpulan}

Berdasarkan hasil analisis data diketahui bahwa baik secara deskriptif maupun secara inferensial, PBL berbantuan multimedia interaktif dapat meningkatkan hasil belajar matematika siswa kelas VII dengan peningkatan rata-rata hasil belajar matematika siswa sesudah diajar dengan model PBL berbantuan multimedia interaktif sebesar 21,2 satuan dengan nilai signifikansi sebesar 0,00. Dengan demikian, PBL berbantuan multimedia interaktif dapat menjadi alternatif bagi guru matematika untuk meningkatkan 
keaktifan dan kemampuan matematik siswa, yang dapat berdampak pada peningkatan hasil belajar matematika siswa.

\section{Ucapan Terima Kasih}

Ucapan terima kasih ditujukan kepada Direktorat Pendidikan Tinggi Agama Islam Kementerian Agama RI yang telah mendanai penelitian ini. Selain itu, ucapan terima kasih juga ditujukan kepada pihak-pihak yang telah terlibat dan membantu terlaksananya penelitian ini.

\section{Daftar Pustaka}

Arends, I. R. (2012). Learning to teach belajar untuk mengajar. Yogyakarta: Pustaka Pelajar.

Boyce, S., \& Norton, A. (2016). Co-construction of fractions schemes and units coordinating structures. The Journal of Mathematical Behavior, 41(1), 10-25.

Darlia, Y., Nasriadi, A., \& Fajri, N. (2018). Penerapan model problem based learning (PBL) dalam meningkatkan kemampuan berpikir siswa pada materi pecahan kelas VII SMP. Jurnal Numeracy, 5(1), 102-118.

DeWolf, M., Bassok, M., \& Holyoak, K. (2015a). Conceptual structure and the procedural affordances of rational numbers: Relational reasoning with fractions and decimals. Journal of Experimental Psychology, 144(1), 127-150.

DeWolf, M., Bassok, M., \& Holyoak, K. (2015b). From rational numbers to algebra: Separable contributions of decimal magnitude and relational understanding of fractions. Journal of Experimental Child Psychology, 133(1), 72-84.

Fyfe, E. R., DeCaro, M. S., \& Rittle-Johnson, B. (2014). An alternative time for telling: When conceptual instruction prior to problem solving improves mathematical knowledge. British Journal of Educational Psychology, 84(3), 1-13.

Gufron, A., Darwan, \& Winarso, W. (2018). Penggunaan bahan ajar berbasis multimedia interaktif terhadap hasil belajar matematika siswa. Inspiramatika: Jurnal Inovasi Pendidikan dan Pembelajaran Matematika, 4(2), 77-88.

Hadi, A. L., \& Dedyerianto. (2020). Analisis data miskonsepsi siswa sekolah menengah pertama dalam menyelesaikan operasi aritmatika dasar. AlTa'dib: Jurnal Kajian Ilmu Kependidikan, 13(1), 18-33.

Halistin. (2018). Analisis pengetahuan dasar matematika siswa SMP negeri di Kota Kendari. Al-Ta'dib: Jurnal Kajian Ilmu Kependidikan, 11(2), 37-54.

Halistin, Kadir, \& Masi, L. (2015). Deskripsi pengetahuan dasar matematika 
siswa kelas IX SMP negeri se-Kota Kendari. Jurnal Pendidikan Matematika, 6(1), 17-29.

Hendra, H. (2016). Peningkatan hasil belajar matematika siswa dengan media komputer model tutorial interaktif pada materi trigonometri kelas X-6. Jurnal Cendekia: Jurnal Pendidikan Matematika, 1(2), 41-50.

Hui, C. (2014). A comparative analysis of British and Taiwanese students' conceptual and procedural knowledge of fraction addition. International Journal of Mathematical Education in Science and Technology, 45(7), $1-3$.

Hurst, M., \& Cordes, S. (2018). Children's understanding of fraction and decimal symbols and the notation-specific relation to pre-algebra ability. Journal of Experimental Child Psychology, 168(1), 32-48.

Jacobsen, D. A., Eggen, P., \& Kauchak, D. (2009). Methods for teaching: Metode-metode pengajaran meningkatkan belajar siswa TK-SMA. Yogyakarta: Pustaka Pelajar.

Kalimatusadiah, Runisah, \& Lestari, W. D. (2019). Model problem based learning berbasis strategi mathematical habits of mind berbantuan multimedia interaktif untuk meningkatkan kemampuan penalaran matematis siswa SMP. Seminar Matematika dan Sains, September, 211-217.

Khasanah, M. U., \& Hartono. (2017). Pengembangan multimedia pembelajaran matematika interaktif berorientasi problem based learning pada materi faktorisasi bentuk aljabar untuk siswa SMP kelas VIII. Jurnal Pendidikan Matematika, 6(8), 81-86.

Khoiri, W., Rochmad, \& Cahyono, A. N. (2013). Problem based learning berbantuan multimedia dalam pembelajaran matematika untuk meningkatkan kemampuan berpikir kreatif. Unnes Journal of Mathematics Education, 2(1), 114-121.

Maonde, F., Bey, A., \& Adawia. (2017). Deskripsi perbedaan pengetahuan dasar matematika siswa kelas VII SMP negeri dan SMP swasta di Kota Kendari tahun pelajaran 2016/2017. Jurnal Pendidikan Matematika, $7(2), 125-138$.

Merritt, J., Lee, M. Y., Rillero, P., \& Kinach, B. M. (2017). Problem-based learning in K-8 mathematics and science education: A literature review. The Interdisciplinary Journal of Problem-Based Learning, 11(2), 5-17.

Patih, T. (2016). Analisis pengetahuan dasar matematika siswa SMP Negeri 3 Kendari sebagai gambaran persiapan siswa dalam menghadapi ujian nasional. Al-Ta'dib: Jurnal Kajian Ilmu Kependidikan, 9(1), 182-200.

Pertiwi, N. L. S. A., \& Dibia, I. K. (2018b). Penerapan model problem based learning berbantuan media interaktif untuk meningkatkan hasil belajar matematika siswa. Journal of Education Action Research, 2(4), 331339. 
Pinahayu, E. A. R. (2017). Problematika penerapan model pembelajaran problem solving pada pelajaran matematika SMP di Brebes. Jurnal Penelitian Pendidikan Matematika, 1(1), 77-85.

Putra, N. A., Sudia, M., \& Arapu, L. (2020). Pengaruh model problem based learning terhadap kemampuan pemahaman konsep matematis peserta didik Kelas VIII SMP Negeri 8 Kendari. Jurnal Penelitian Pendidikan Matematika, 8(1), 95-108.

Sartika, R. (2017). Pengaruh penerapan model problem based learning berbantuan media pembelajaran interaktif terhadap kemampuan komunikasi matematika, kemampuan penalaran dan kemampuan pemahaman konsep matematika bagi siswa kelas X MAN 1 Kota Bengkulu. Jurnal Pendidikan Matematika Raflesia, 2(1), 108-117.

Schindler, M., \& Hußmann, S. (2013). About students' individual concepts of negative integers - in terms of the order relation. CERME 8, February 2016, 373-382.

Siegler, R., Clarissa, T. A., \& Schneider, M. (2011). An integrated theory of whole number and fractions development. Cognitive Psychology, 62(4), 273-296.

Siswono, T. Y. E. (2018). Pembelajaran matematika berbasis pengajuan dan pemecahan masalah. Bandung: Remaja Rosdakarya.

Sitriani, Kadir, Arapu, L., \& Ndia, L. (2019). Analisis kemampuan numerik siswa SMP negeri di Kota Kendari ditinjau dari perbedaan gender. Jurnal Pendidikan Matematika, 10(2), 161-171.

Sukmana, A. I. W. I. Y., Candiasa, I. M., \& Kirna, I. M. (2013). Pengembangan multimedia pembelajaran matematika berpendekatan kontekstual untuk siswa Kelas VIII di SMP Negeri 4 Singajara. EJournal Program Pascasarjana Universitas Pendidikan Ganesha, Program Studi Teknologi Pembelajaran, 3(1), 1-13.

Tarmizi, R. A., \& Bayat, S. (2012). Collaborative problem-based learning in mathematics: A cognitive load perspective. Procedia-Social and Behavioral Sciences, 32(2011), 344-350.

Tyas, R. (2017). Kesulitan penerapan problem based learning dalam pembelajaran matematika. Tecnoscienza, 2(1), 43-52. 